\title{
İmalât Sanayi Firmalarında Sınaî Mülkiyet Koruma Tercihleri
}

\author{
Hakan EREN*
}

\author{
Ali KILIÇ**
}

\begin{abstract}
$\ddot{O} Z$
Bu çalışma, gelişmekte olan bir ülkede, firmaların sınai mülkiyet koruma tercihlerini ve korumaya verdikleri önemi etkileyebilecek bir dizi faktörü ampirik olarak incelemektedir. Çalışmada, Türkiye İstatistik Kurumunun Yenilik Araştırması 2012 verisinden yararlanılmıştır. Analizlerde, ürün sunulan pazar büyüklügü̈, Ar-Ge aktiviteleri, istifade edilen bilgi kaynaklarl ve destekler gibi geleneksel faktörlerin yanısıra, organizasyonlar arası işbirlikleri ve farklı kurumsal stratejilerin etkilerine odaklanılmıştır. Henüz SM korumasının ilk aşamasında olunmasına rağmen, genel olarak farkl koşullar altında firmaların resmi ve stratejik koruma yöntemleri arasindan tercihte bulunduğu görülmektedir. Sonuçlar, bir firmanın patent/FM koruma davranışının, firmanın yenilik stratejisine sahip olması ve daha çok dişa dönük yenilik faaliyetleri ile ilişkili olduğunu göstermektedir. Kurum içi ve piyasa temelli bilgi kaynakları ile yenilik stratejisi, tüm koruma yöntemleri üzerinde pozitif etkiye sahiptir. Diğer firma ve bilgi merkezleri ile işbirliklerinde patent/FM ve gizlilik birbirlerinin tamamlayıcısıdır. Sonuçlar ayrıca, marka tescili, patent/FM ve üretim süresi avantajının, ürün yeniliğini anlaml olarak en fazla oranda etkileyen koruma yöntemleri olduğunu göstermiştir.
\end{abstract}

Anahtar Kelimeler: Sinaî Mülkiyet, Koruma Yöntemleri, Gelişmekte Olan Ülke, Kurumsal Stratejiler, Sirall Lojistik Regresyon

JEL Sinıflandırması: O31, O32, O34

\section{Intellectual Property Protection Preferences of Manufacturing Firms}

\begin{abstract}
This article explores the IP protection in a developing country by using a set of factors that may drive IP protection method preferences of firms and the importance they attach to the protection. Empirical analyses are based on the Turkish Community Innovation Survey 2012 data. The analysis focuses on inputs including different types of corporate strategies and cooperation in addition to traditional factors such as market size, $R \& D$ activities, knowledge sources and funds. Despite being in early stages of IP system, firms use both formal and informal protection mechanisms under different circumstances. Our results indicate that patents/UM protection behavior of firms is mostly associated with having an innovation strategy and outward-oriented innovation activities. Internal and market-based information sources and innovation strategy have a positive effect on all protection methods. Patent/UM and secrecy are complementary to each other in cooperation with other firms and information centers. Our results also confirm that trademark registration, patent/UM and lead-time advantages are the protection methods that significantly influence product innovation.
\end{abstract}

Key Words: Intellectual Property, Protection Mechanisms, Developing Country, Corporate Strategies, Ordered Logistic Regression

JEL Classification: O31, O32, O34

\footnotetext{
*Dr., Jandarma Genel Komutanlı̆̆ı, Teknoloji Yönetimi AD, hkneren@yahoo.com

** Dr., Kara Kuvvetleri Komutanlı̆̆ı, Teknoloji Yönetimi AD, alikilic33@yahoo.com
} 


\section{GíRiş}

Son yıllarda firmalar, sürdürebilir büyüme sağlamak ve rekabetçi avantaj kazanmak maksadiyla bilgi temelli faaliyetlere daha fazla önem vermeye başlamıştır. Bilginin üretilmesi ve ticari değere dönüştürülmesi sürecinde birçok farklı yöntem kullanarak sahip oldukları bilgi varlıklarını koruma yaklaşımı geliştirmektedirler. $\mathrm{Bu}$ durum, Sınâ̂ Mülkiyet (SM) araştırmalarına artan derecede ilgi duyulmasına yol açmaktadır.

Yenilikçi faaliyetler ile edinilen değerli bilginin korunması arasında pozitif yönlü bir ilişki mevcuttur. Korumanın içerdiği teknik bilgi paketi Ar-Ge faaliyetlerinin başlatılmasına ve yenilikçi fikirlerin geliştirilmesine olanak sağlayarak bilginin çoğalmasına ve yayılmasına katkıda bulunmaktadır. Ayrıca sağlanan koruma, firmalarda yenilikçi bir kültürün geliştirilmesinde ve bilginin rakipler tarafından kopyalanmasını engellenerek rekabetçi avantaj kazanılmasında etkili rol oynamaktadır (Cohen vd, 2000; Blind vd, 2006; Amara vd, 2008; Shukla, 2005). Bu avantajlarına rağmen gerek yasal altyapı gerekse sınaî koruma rakamları açısından gelişmekte olan ülkeler, gelişmiş ülkelerin oldukça gerisinde bulunmaktadır (The World Intellectual Property Organization, WIPO, 2012). Genel olarak bu durumun en önemli nedenleri arasında, yenilikçi kültürün önemli koşullarından olan Ar-Ge ve finansal kaynak eksiklikleri, üniversite-sanayi işbirliğinin etkin olarak gerçekleştirilememesi, yenilik ve koruma konusunda yetersiz farkındalık ile korumanın getirdiği yüksek maliyetlerin olduğu belirtilmektedir (Dericioğlu, 2005; Shukla, 2005). Gelişmekte olan ülke kategorisinde olan ülkemizde konuya verilen önem ve son y1llarda koruma konusunda gerekli yasal tedbirlerin yürürlüğe girmesi açısından önemli gelişmeler yaşanmaktadır.

SM koruma yöntemleri; resmi veya yasal (patent, faydalı model (FM), tasarım tescili, telif hakkı ve ticari markalar), resmi olmayan veya stratejik koruma yöntemleri (üretim süresi avantajı, tasarımın karmaşıklığı ve gizlilik) olarak iki ana bölüme ayrılmaktadır (Amara vd, 2008; Gallie ve Legros, 2012; Thomä ve Bizer, 2013). Türkiye'de konu üzerinde yapılan çalışmaların daha çok patent ve markayı kapsadığı tespitinden hareketle (Eren ve Kılıç, 2016; Pekol ve Erbaş, 2011; Yalçıner ve Akın, 2009), firmaların diğer stratejik koruma yöntem tercihlerinin ve etki eden faktörlerin incelenmesinin literatüre ayrıca bir katkı sağlayacağı değerlendirilmektedir.

Koruma yöntemlerinin firmaya sağladığı faydalar ile yeniliğin derecesine ve firmaya getireceği maliyete göre firmaları farklı yöntemler arasından hangi yöntemi seçeceğine yönlendiren motivasyonları ele alan ampirik çalışmalar bulunmaktadır (Blind vd, 2006; Kay vd, 2014; Olsson ve McQueen, 2000; Shukla, 2005; Duguet ve Kabla, 1998; Amara vd, 2008; Gallié ve Legros, 2012). Firmaların koruma kararları üzerinde etkisi olan, firmanın özellikleri ve pazarın durumunu ifade eden faktörler, iç ve dış faktörler olarak gruplandırılabilir. Geçmiş yıllarda firma seviyesinde yapılan ampirik çalışmalarda, pazar ve firma büyüklüğü, bilgi kaynakları, Ar-Ge faaliyetleri, diğer aktörler ile işbirlikleri, finansal destekler ve yenilik türleri gibi faktörler, koruma yöntemlerinden 
beklenen etkinlik değerlendirilmesinde ve firmaların tercihlerindeki farklılıkların nedenlerinin incelenmesinde kullanılmıştır (Duguet ve Kabla, 1998; Brouwer ve Kleinknecht, 1999; Cohen vd, 2000; Peeters ve Pottelsberghe de la Potterie, 2006; Kay vd, 2014; Gallié ve Legros, 2012). Yapılan çalışmaların büyük çoğunluğu, koruma tercihlerini özellikle gelişmiş ülkelerin perspektifinden ele almıştır. $\mathrm{Bu}$ çalışma, yukarıda belirtilen faktörlerin koruma tercihleri üzerindeki etkileri yanında yeniliğin önemli bir kaynağı olduğu kabul edilen kurumsal stratejilerin etkilerini de birlikte inceleyen ilk çalışma olacaktır. Ayrıca büyük bir örneklemle yapılan çalışmanın, gelişmekte olan ülkelerde firmaların koruma tercihleri ve korumaya verilen önemin ortaya çıkarılması açısından mevcut literatüre katkıda bulunacağı öngörülmektedir.

Yukarıda belirtilen değerlendirmeler doğrultusunda bu çalışmada, farklı büyüklükte ve aktif olarak yenilik faaliyetinde bulunan firmalarda, farklı koruma stratejilerinin tercih edilmesini sağlayan öncüllerin neler olduğunun ampirik olarak ortaya çıkarılması ve koruma faaliyetinde etkisi olan iç ve dış faktörlerin etki derecelerinin belirlenmesiyle literatürdeki boşluğun doldurulması amaçlanmıştır. Çalışmada, firma seviyesinde bilgi içeren Türkiye İstatistik Kurumunun (TÜIK) Yenilik Araştırması 2012 verisinden yararlanılmıştır.

Çalışma, üç bölümden oluşmaktadır. Giriş bölümünü takiben birinci bölümde literatürdeki çalışmalardan istifade edilerek, koruma yöntemleri kavramsal olarak ele alınmış, koruma stratejisine etki eden faktörler incelenmiştir. İkinci bölümde, kullanılan yöntem, veri ve verinin düzenlenmesi belirtildikten sonra üçüncü bölümde elde edilen bulgulara yer verilmiş ve sonuçlar tartış1larak yorumlanmıştır.

\section{LITERATÜR TARAMASI}

\section{A. Koruma Yöntemleri}

Yasal açıdan SM koruma yöntemleri başvuru sahiplerine; üçüncü tarafların kendi icatları, yenilikleri, tasarım ve markalarını taklit etme, satma veya bünyelerine almalarını önlemek için yasayla tanınan bir dizi münhasır hak sağlamaktadır (WIPO, 2016). Sahiplere sağlanan bu haklar, diğerleri için de zorlu bir rekabet ortamının doğmasına neden olmaktadır.

Patent, tartışmasız en güçlü SM koruma şeklidir. Yeni ve ticari olarak uygulanabilir bir buluşu sınırlı bir süre (Türkiye'de incelemesiz 7, incelemeli 20 yıldır.) ve belirli bir yer için üretme, kullanma ve satış gibi hakları tanıyan belgedir (TPE, 2015). Patent belgesi, buluş sahibinin fikrini açıklama, pazarlama ve başkalarının kullanması için yetkilendirme hakkına sahip olduğunu gösterir. Elde edilme süresi uzun ve masraflıdır. Yeni buluşları korumanın bir başka yolu olan ve patente benzeyen faydalı model korumas1, mevcut ürünler üzerinde yapılan yeni uygulamaları ve iyileştirmeleri kapsayan kısmi yeniliklere daha kısa bir süre için verilmektedir (7-10 yıl) (WIPO, 2012). Türkiye'de bu süre 10 yıldır. Küçük ve orta ölçekli firmalar ile araştırma kuruluşlarının buluş yapmaları ve bunları sanayiye uygulamalarını özendirdiği için özellikle gelişmekte olan ülkelerde patentten daha yaygın olarak tercih edilmektedir. Patente göre daha kısa 
sürede ve düşük maliyetle koruma elde edilmesini sağlayan FM koruması, patent verilebilirlik şartlarından birisi olan, "tekniğin bilinen durumunun aşılması" ölçütünü gerektirmemektedir. SM ve ulusal düzeyde ekonomik büyüme arasındaki ilişki üzerine yapılan önceki çalışmalarda FM koruması patentle birlikte ele alınmıștır (Lederman ve Saenz, 2005; Kim vd, 2012).

Bazen tasarım patenti olarak da adlandırılan endüstriyel tasarımın sicil kaydı, ürünün dekoratif veya estetik yönünü korumaya yaramaktadır. Tasarımı oluşturan görsel özellikler, ürünün hatları, renkleri, şekli, dokusu, malzemesi ve ürüne uygulandığında ona özgün bir görünüm vermeyi sağlayan süsleme gibi unsurları içerir. Ancak ürünün nasıl çalıştığ 1 ya da hangi materyalden yapıldı̆̆ 1 koruma altına alınmaz (WIPO, 2016; Gallié ve Legros, 2012). Tescil edilebilmesi için tasarımın yeni ve kendine özgü özellikleri olması gerekmektedir. Telif hakkı, genel olarak edebiyat ve sanat eserleri için kullanılmaktadır. Telif; kitap, müzik, resim, heykel ve filmlerden, bilgisayar programları, veri tabanları, reklamlar, haritalar ve teknik çizimlere kadar uzanmaktadır (WIPO, 2016). Ticari marka ise, ürün veya hizmetlerin ticari kaynağının göstergelerini koruyan bir işaret veya özgün bir ifadedir. Ticari marka tescilleri de periyodik olarak (genellikle her 10 yil) yenileme gerektirmektedir.

Başvuru maliyetlerinin yüksek olması, yasal koruma yöntemleri konusundaki yetersiz bilgi ve farkındalıkla ilgili eksiklikler, bilginin açığa çıkmasının dezavantajları gibi nedenler (Uysal, 2012), firmaları resmi olmayan koruma yöntemlerini kullanmaya yöneltmektedir. Bunlardan ilki, üretim süresi avantajıdır. Yeniliğin başlatılması ile geliştirilmesi arasındaki sürenin azaltılmasını ifade eden bu strateji, rakiplerden daha hızlı yeniliklerin hayata geçirilmesini sağlayarak firmaların belirli bir süre için rekabette bir teknolojik avantaj kazanmasına yardımcı olur (Delerue ve Lejeune, 2010). Bir diğer koruma stratejisi olan tasarımın karmaşıklığı, geniş yelpazede farklı teknolojiler içeren ürünün, bileşenleri ve alt sistemlerinin entegrasyonunun taklidi önleyecek şekilde yapılmasıdır. Rakipler karşısında avantaj kazandıran gizlilik ise; formül, cihaz, yöntem, teknik veya süreçler gibi bir firmanın sahip olduğu bilgilerin gizli tutularak rakiplerden korunmasıdır. Ancak ticari sırlar, yeni keşiflere veya tersine mühendisliğe karşı koruma sağlamamaktadır (Gallie ve Legros, 2012).

Literatürde üzerinde en çok çalışılan konu, bir firmanın patent ve gizlilik arasındaki tercihidir. Yapılan bu çalışmalarda imalât firmalarının, stratejik değer ve fayda elde etmek için en etkili yol olarak patenti tercih ettikleri iddia edilmektedir (Macdonald, 2004; Markman vd, 2004). Gizlilik, radikal yenilikler ve buluşlar için etkili bir yöntem olarak öne çıkmaktadır (Levin vd, 1987; Cohen vd, 2000). Finansal kaynakların yetersiz olması, gizliliğin tercih edilmesindeki diğer bir etkendir. Yine bazı araştırmacılar, firmaların farklı nedenlerle resmi olmayan koruma stratejilerini patente nazaran daha fazla kullandıklarını belirtmektedirler (Cohen vd, 2000; Laursen ve Salter, 2014). Nitekim firmalar tarafindan hangi koşullarda hangi yöntemin seçileceğine yönelik bir görüş birliği henüz oluşmamıştır. Fakat oluşan genel kanı, farklı pazar ve firma koşullarının bu tercihlere etki ettiği şeklindedir. Gallié ve Legros (2012), Fransız imalât sanayi 
firmalarında yaptıkları çalışmada, resmi ve resmi olmayan koruma yöntemlerinin eşit oranlarda kullanıldığını bulmuşlardır. Aynı çalışmada en yaygın kullanılan koruma yöntemleri ise ticari marka, üretim süresi avantajı ve patent olarak tespit edilmiştir. Leiponen ve Byma (2009), küçük firmaların, patenti en önemli koruma mekanizması olarak görmediğini, gizlilik ve üretim süresi avantajını kullandıklarını ortaya çıkarmıştır. Thomä ve Bizer (2013)'a göre, gizlilik ve pazara hızlı girilmesi, genellikle resmi yöntemlerle birleştirilmekte ve küçük firmalar patent korumasının yerine tasarımın karmaşıklığını kullanmaktadırlar.

\section{B. SM Koruma Strateji Tercihlerini Etkileyen Faktörler}

SM literatürü, firmaların çeşitli yenilik koruma mekanizmalarına eğilimlerini açıklarken farklı faktörlerin etkisini ele almaktadır. Bu faktörler genel olarak, firmanın mevcut durumunu ve içinde bulunduğu koşulları vurgulamaktadır. Firmaların yenilikçi faaliyetler geliştirmesi ile SM sahip olması doğru orantılı olduğundan (Hanel, 2008; Thomä ve Bizer, 2013), yenilikçi aktiviteler ve performansı tanımlarken kullanılan faktörlerle korumayı belirleyen etkenler genel olarak birbirleriyle örtüşmektedir. Firmanın mevcut koşulları ve dış çevresinin özellikleri arasında geçmiş çalışmalarda, Ar-Ge için ayrılan kaynaklar, pazar ve firma büyüklüğü, firmanın sektörde faaliyet süresi, aldığı destekler, bilgi stratejileri ve işbirliği aktiviteleri yaygın olarak kullanılan faktörlerdir (Blind vd, 2006; Kay vd, 2014; Peeters ve Pottelsberghe de la Potterie, 2006). Koruma kararları üzerinde etkisi olması beklenen faktörlerin belirlenmesi kapsamında bu çalışmada, pazar büyüklüğü, Ar-Ge faaliyetleri, finansal destekler, bilgi kaynakları, farklı aktörlerle yapılan işbirlikleri ve dört kurumsal stratejinin (pazarlama, maliyet, yenilik ve işbirliği stratejisi) muhtemel etkileri incelenmektedir.

Faaliyet yürütülen pazarın büyüklüğ̈̈, bu faktörlerden birisidir. Literatürdeki birçok çalışmada genel olarak pazar büyüklügünün koruma kararları üzerinde pozitif etkisi olduğu belirlenmiştir. Schumpeter'in "rekabet düzeyi yüksek olan piyasa yapılarında faaliyet yürüten firmalar yenilik için daha fazla motivasyona sahiptir" hipotezi doğrultusunda, yüksek pazar gücüne sahip firmalar Ar-Ge faaliyetlerini daha yüksek oranda finanse edebilir ve bu nedenle daha aktif yenilikçi olurlar (Keller, 2004). Ayrıca dış pazarlara yönelen firmalar, teknoloji izleme ve kurulan ilişkilerle öğrenme etkisinden de daha fazla istifade ederler. Pazarı dar firmaların ise finansal kaynak kısıtları nedeniyle koruma yöntemlerini daha az kullanması beklenmektedir. Gallié ve Legros (2012) çalışmalarında, pazar payı yüksek firmaların taklide karşı kendilerini korumaya daha fazla ihtiyaç duyduğunu belirlemiştir. Yüksek pazar gücüne sahip firmalar, patent ve gizlilik mekanizmalarını tercih etmektedirler (Keller, 2004). Çünkü patentleme stratejisinin, firmanın teknolojik imajını ve değerini artırma amacı bulunmaktadır (Blind vd, 2006). Ayrıca küresel piyasalarda ticari markaların önemi de resmi koruma yöntemlerine olan yönelime işaret etmektedir.

Literatürde üzerinde en fazla çalışlan konulardan birisi, Ar-Ge seviyesi ve SM arasındaki ilişkidir. Ar-Ge faaliyetleri ve tahsis edilen kaynaklardaki artış, 
kodlanan bilginin ve korunacak buluşların sayısının da artmasına katkı sağlamaktadır (Blind vd, 2006; Duguet ve Kabla, 1998; Brouwer ve Kleinknecht, 1999; Gallié ve Legros, 2012). Amara vd (2008), Ar-Ge yoğunluğunun, en yüksek etkisi gizlilik üzerinde olmak üzere, patent, marka, tasarımın karmaşıklığ1 ve üretim süresi avantajı ile pozitif ve anlamlı ilişkisi olduğunu bulgulamışlardır. Ayrıca beklentilerinin aksine elde ettikleri sonuçların, resmi olmayan koruma yöntemleri ile Ar-Ge arasında daha fazla ilişkinin varlığına işaret ettiğini belirtmişlerdir. Gallié ve Legros (2012) ise iç bilgi kaynaklarına odaklanan ve yoğun Ar-Ge çalışmaları yürüten firmaların gizliliğe daha fazla önem verdiğini ve dış Ar-Ge’nin resmi koruma yöntemlerine yönelttiğini tespit etmişlerdir.

Firmalar kendi öz varlıklarının yanı sıra, ürün geliştirmede ve ürünün ticarileştirilmesinde diğer dış finansman kaynaklarını ve araştırma desteklerini kullanmaktadırlar (Lerner, 1999; Kay vd, 2014). Yapılan çalışmalarda, firmaların resmi SM koruma yöntemleri kullanmasının önündeki en büyük engel olarak başvuru ve sonrasında hukuki süreçlerdeki savunma maliyetlerinin olduğu kabul edilmektedir (Cohen vd, 2000; Sichelman ve Graham, 2010; Uysal, 2012). Finansal teşviklerin, maliyet kaynaklı bu olumsuz etkinin ortadan kaldırılmasında ve firmaların koruma algısı yönünde istekliliğine olumlu etkisi olacağı öne sürülebilir.

İç ve dış bilgi kaynaklarının yenilik sürecinde stratejik olarak önemli olduğu araştırmalarda vurgulanmaktadır (Nonaka ve Takeuchi, 1995; Elche, 2011). Firmalar yenilik süreçlerinde, finansal destekler ve iç Ar-Ge imkânlarını kullanırken, dış bilgiye erişmek, ortak Ar-Ge yaparak riskleri ve yenilik maliyetlerini diğer kuruluşlarla paylaşmak ve teknolojik olarak gelişimlerini sağlamak amacıyla diğer firmalar, kuruluşlar, üniversiteler ve müşterilerle işbirlikleri yürütürler (Laursen ve Salter, 2014; Kay vd, 2014; Chesbrough, 2003). Nitekim yenilikleri geliştirmek genellikle açık olmayı gerektirirken, yeniliklerin ticarileştirilmesi ise korumayı ön plana çıkarmaktadır. Özellikle açık yenilik yaklaşımı izleyen firmalar, SM koruması gerektirecek teknolojileri geliştirebilmek için artan oranda diş bilgi kaynaklarına ilgi göstermekte ve kullanmaktadirlar (Chesbrough, 2003). Tether (2002)'a göre, özellikle radikal yenilik geliştirmeye çalışan firmalar, bilgi kaynaklarına daha fazla ihtiyaç duyarlar. Her ne kadar araştırma ve bilgi üretimi faaliyeti için firma içi imkânlar yenilik sürecindeki önemli girdiler olarak değerlendirilse de firmaların tek başlarına bu bilgiyi üretmeleri ve sahip olmaları genellikle zordur. $\mathrm{Bu}$ nedenle birçok firma, iç ve dış bilgi kaynaklarını birlikte kullanırlar (Elche, 2011).

Firmalar diş bilgilere erişmek, tamamlayıcı bilgilerden sinerji yaratmak, risk ve yenilik maliyetlerini paylaşmak, teknik destek alabilmek ve yüksek maliyetli laboratuvar ekipmanları ile araştırma altyapısını kullanmak için çok sayıda aktörle işbirliği yaparlar. Araştırmalar, dış işbirlikleri gerçekleştiren firmaların, bilgilerini korumaya daha fazla ihtiyaç duyduklarını göstermektedir (Cassiman ve Veugelers, 2002). Diş kuruluş ve aktörlerle kurulan işbirlikleri, bilginin ya da ekipmanın ortak kullanımını gerektirdiğinden, koruma ihtiyacının artması da doğaldır. Bu korumanın özellikle firmaları, işbirliği sonucu ortaya 
çıkacak ürünler üzerinde ileride yaşanabilecek sahiplik anlaşmazlıklarını da gidermek için resmi koruma yöntemlerine yönelttiği savunulmaktadır (Peeters ve Pottelsberghe de la Potterie, 2006; Brouwer ve Kleinknecht, 1999; Gallié ve Legros, 2012). Koruma üzerinde etkisi olan işbirliği ilişkilerinde ortakların türü de SM koruma tutumlarını belirlenmesinde önemlidir (Peeters ve Pottelsberghe de la Potterie, 2006). Üniversitelerle işbirlikleri, personel, üniversite altyapısı ve ekipmanları ile bilgi transferi ağırlıklı olarak yürütülmektedir (Löfsten ve Lindelöf, 2002). Üniversite ve araştırma kurumları ile işbirliği kurulması ile teknoloji avantajı sağlanırken, firmaların temel araştırmalara dayalı radikal yenilikler geliştirerek pazara yeni ürünler sunabilme yetenekleri artmakta (Kaufmann ve Tödtling, 2001) ve bu nedenle diğer firmalara göre koruma yöntemlerinin yararına daha fazla inanmaktadırlar (Leiponen ve Byma, 2009).

Diğer taraftan firmalarla yapılan işbirlikleri sonucunda karşılıklı öğrenme ile ortakların özel bilgi ve uzmanlıklarından yararlanma firsatı yakalandığı, böylelikle daha çok pazar avantajı sağlandığı ifade edilmektedir (Sobrero ve Roberts, 2002). Ancak diğer firmalar ile işbirliğinde, bilgi paylaşımı sürecinde istenmeyen kayıplar yaşanma olasılığı artacağından, firmaların kendi bilgilerinin rakipleri tarafından kopyalanmasına karşı koruma gerekliliği de artacaktır (Cassiman ve Veugelers, 2002; Blind vd, 2006; Laursen ve Salter, 2014). Leiponen ve Byma (2009)'ya göre, yüksek Ar-Ge yatırımı olan ve üniversite/araştırma kuruluşları ile işbirliği yapan firmalar, korumanın öneminin daha fazla farkındadırlar. Amara vd (2008) yaptıkları çalışmada, araştırma kuruluşları ile bilgi paylaşımı yapmanın, telif hakları, ticari markalar ve gizliliği seçme olasıllı̆ı üzerinde olumlu bir etkiye sahip olduğunu bulmuşlardır. Leiponen ve Byma (2009) tarafından yapılan çalışmada ise sadece teknoloji odaklı firmaların üniversite ile işbirliklerinde en önemli yöntem olarak patent tercihinin öne çıktığı, ancak firmaların büyük çoğunluğunun patentten daha çok gizlilik ve üretim süresi avantajını tercih ettikleri belirlenmiştir.

Firmalar, farklı stratejiler benimseyerek ve izleyerek, cirolarını ve kârlarını artırma veya maliyetlerini azaltma gibi bazı hedeflere ulaşmak için yoğun çaba göstermektedirler. Kurumsal stratejinin bir parçası olan koruma stratejileri, taklidi önleyerek firmaların gelişimi ve rekabet avantajı kazanmalarına yardımcı olma ve firmaların hedeflerini sağlama amacıyla etkin bir araç olarak hizmet ederler. Kurumsal stratejiler (pazarlama, maliyet, yenilik ve işbirliği) ile SM koruma yöntemleri arasındaki olası etkileri incelemek, SM yönetimine yönelik tutumlar hakkında yararlı bilgiler sağlayabilecektir. Örneğin, firmanın benimsediği bir pazarlama stratejisi varsa, yenilikleri korumak için hangi koruma stratejilerine önem verdiği ortaya çıkarılabilecektir.

\section{YÖNTEM VE VERI}

A. Yöntem

Koruma stratejileri üzerinde, bağımsız değişkenlerin etkisini incelemek üzere hem tanımlayıcı istatistikler hem de çok değişkenli yöntemler kullanılmıştır. Analizlerin ilk bölümünde, yenilik araştırmasında firmaların ürün 
yeniliği geliştirip geliştirmediği ikili ölçek kullanılarak belirlendiğinden, farklı koruma yöntemlerinin ürün yeniliği üzerindeki etkileri ikili (binary) lojistik regresyon analizi kullanılarak incelenmiştir. İkili lojistik regresyon analizi, bağımlı değişkenin iki kategorili cevap niteliği taşıdığı, bağımsız değişkenin ise herhangi türden olabildiği durumlarda kullanılan istatistiksel bir yöntemdir. İkinci aşamada, gerçekleştirdikleri yenilik faaliyetlerinin yoğunluğuna göre firmaları sınıflandırmak maksadıyla kümeleme analizi yapılmıştır. Kümeleme analizi, büyük miktardaki verinin, nispeten kendi içlerinde homojen ve birbirleriyle heterojen gruplar halinde sinıflandırılmasını sağlayan bir veri indirgeme tekniğidir. Firmalar bu analizle benzerliklerine göre kümelere veya gruplara ayrılabilmektedir. Böyle bir gruplamanın, firmaların yenilik faaliyetlerine katılım düzeyindeki farklılıkların, koruma stratejileri hakkındaki algılar üzerindeki etkisinin ortaya çıkarılmasında yararlı olacağı değerlendirilmektedir. Üçüncü aşamada, firmalar tarafından koruma yöntemlerine verilen önem üzerinde çok sayıda faktörün aynı anda etkisini incelemek maksadıyla sıralı lojistik regresyon analizi kullanılmıştır. $\mathrm{Bu}$ yöntem, tüm bağımlı değişkenlerin dört kategoride cevap içermesi ve sıralama ölçeğiyle elde edilmiş olmaları nedeniyle seçilmiştir. Analizlerde ayrıca, tanımlayıcı istatistikler, parametrik olmayan testler ve faktör analizi gibi farklı istatistiksel yöntemler de kullanılmıştır. Veri analizinde SPSS v21 paket programından yararlanılmıştır.

\section{B. Veri}

TÜIK' in, Türkiye'deki yenilik faaliyetlerinin seviyesini ölçmek maksadıyla Oslo Kılavuzu doğrultusunda hazırladığı ve 2010-2012 yılları arasındaki üç yıllık dönemi kapsayan 2012 yılı Yenilik Araştırması veri tabanından yararlanılmıştır. Söz konusu araştırma, TÜİK tarafından iki yılda bir, üç yıllık dönemlere ilişkin yapılmakta ve sonuçları yayınlanmaktadır. Yenilik araştırması; Ar-Ge harcamaları, işbirlikleri, bilgi kaynakları, destekler ve yenilik ortaya çıkarmak için firmaların kapasitesini etkileyen diğer faktörler gibi güncel yenilik faaliyetleri hakkında ayrıntılı veri kaynağı sağlamaktadır. Ayrıca yeniliklerin korunması için tercih edilen koruma yöntemleri ile ilgili de bilgi içermektedir. Yenilik Araştırması verileri, sanayi ve hizmet sektöründe faaliyet gösteren, 10 ve daha fazla çalışanı olan girişimlerden, örnekleme yöntemi ile tespit edilenlerden firma seviyesinde elde edilmiştir. Yenilik Araştırması 2012 toplam 9.342 firmadan elde edilen verileri kapsamaktadır. Frenz ve Prevezer (2012)'e göre, yenilik anket verilerinin diğer kaynaklara göre en önemli avantajları; farklı sektörlerde firma düzeyinde olması, belirli aralıklarla tekrar etmesi, geniş bir coğrafyada uygulanması ve kapsamlı yenilik göstergelerini içermesidir. Ayrıca bu veri, diğer ülkelerde yapılan çalışmalar ile karşıllaştırılabilecek genellenebilir sonuçlar sunmaktadir (Oliver ve Ripoll, 2015).

Türkiye'de SM alanında firmaların farkındalığının, yapılan bilimsel çalışmaların ve yasal altyapı oluşturma gayretlerinin özellikle son dönemde artmaya başlaması nedeniyle 2012 Yenilik Araştırması verisinden yararlanılmıştır. Sonraki dönem verilerinin kullanılması ile uzun dönemli gelişim konusunda tutarlı bilgiler edinilebilecektir. 


\section{Değişkenler}

Ham veriler; gruplama, logaritma alma, toplama ve ortalama alma gibi matematiksel işlemler ile düzenlenerek araştırmanın amacına uygun yeni değişkenler oluşturulmuştur. Oluşturulan tüm değişkenler Tablo 1'dedir:

Tablo 1. Değişken Açıklamaları

Değişkenler

Bağımlı

Ürün yeniliği

Bağımlı/Bağımsız

Koruma stratejilerine verilen önem derecesi

\section{Bağımsızlar}

Ürün sunulan pazar büyüklüğ̈̈

$\dot{I}_{c ̧}$ ve $\mathrm{d}_{\iota s ̧} \mathrm{Ar}-\mathrm{Ge}$

harcamalart

Finansal destek alma

İşbirliği yapma

derecesi

Bilgi kaynaklarından yararlanma derecesi

Yeniliğe yönelik

faaliyet

gerçekleştirme
Açılama

Firmaların 2010-2012 yılları arasında piyasaya yeni ya da önemli oranda geliştirilmiş/iyileştirilmiş mal sunması durumunda tüm cevaplar 1, aksi halde 0 ile kodlanmıştır.

Ürün ve süreç yeniliklerinin rekabetçi avantajının korunması ve artırılmasında kullanılan koruma yöntemlerine (patent/FM, tasarımın sicil kaydı, telif, marka, üretim süresi avantajı, tasarımın karmaşıklığı ve gizlilik) firmalar tarafından verilen önemin derecesidir. Her madde için, "etkisi yok", "az", "orta" ve "çok" seçeneklerinden oluşan dörtlü Likert ölçeğine göre firma değerlendirmeleri alınmıştır. Alınan cevaplar sırasıyla 0-3 kodlanarak kullanılmıştır.

Firmaların dönem içerisinde mal veya hizmet sattığı pazarları ifade etmektedir. Dört farklı pazardan yerel/bölgesel olanlar (1), Türkiye geneli (2), AB ülkeleri ya da aday ülkeleri (3), firmanın satışları diğer ülkeleri de kapsamakta ise (4) değeri verilmiştir. Tüm bu değerler toplanarak 0-10 arasında değer alan değişken oluşturulmuştur.

Firmaların Ar-Ge için yaptıkları harcamaların 2012 yılındaki parasal karşılığıdır. Değişkenler çarpık dağılımı normalleştirmek amacıyla 10 tabanında logaritması alınarak (sıfır değerli gözlemler için 1 eklenmiştir) kullanılmıştır.

Firmanın üç yıllık dönemde, yerel veya bölgesel kamu kuruluşları, merkezi kamu kurum/kuruluşları ve $\mathrm{AB}$ kurumlarından yürüttüğü yenilik faaliyetleri için finansal destek alma durumu 1, almama durumu ise 0 ile kodlanarak kullanılmıştır.

Firmaların yenilik faaliyetlerinin herhangi birinde, diğer firmalar, müşteriler ve bilgi merkezleri ile işbirliği başlatmaları ya da geliştirmeleri durumunda verdikleri cevaplar 1, yapmama durumu ise 0 ile kodlanarak 3 farklı değişken oluşturulmuştur.

Firmaların, bilgi altyapılarını genişletmek için, firma içi, piyasa (müşteriler, rakipler, danışmanlar, ticari laboratuvarlar vb.), üniversite ve araştırma kurumları ile diğer bilgi kaynaklarından (konferanslar, fuarlar, bilimsel dergiler, ticari/teknik yayinlar, dernekler ve meslek odalarl) yararlanma durumu 1, yararlanmama durumu 0 ile kodlanmıştır. Firmaların üç yıllık dönemde yedi çeşit yenilik faaliyetinin (yenilik geliştirmek için yürütülen iç Ar-Ge ve dışarıdan temin edilen Ar-Ge hizmetleri, makina, teçhizat ve yazılım temini, dışsal bilgi temini, eğitim, tanıtım, tasarım ve diğer hazırlıklar) herhangi birisini gerçekleştirme durumu 1, aksi ise 0 ile kodlanmıştır.

\section{BULGULAR}

Korumadan söz edilebilmesi için korumanın gerekeceği yeni bir bilginin ortaya çıkartılmış olması gerektiği açıktır. Bu nedenle bağımlı değişken olarak 
Yenilik Araştırması 2012'ye katılan 4.549 imalât sanayi firmasının ürün yeniliği yapıp yapmadıkları değişkeni kullanılmıştır. Bu doğrultuda ürün yeniliği üzerinde SM koruma mekanizmalarının her birinin etki derecelerinin belirlenmesi ve firmalar tarafından yapılan yöntem seçiminin daha iyi anlaşılmasını sağlamak için ikili lojistik regresyon analizi icra edilmiştir (Tablo 2).

Tablo 2. SM Koruma Mekanizmalarının Ürün Yeniliğine Etkisini Belirleyen İkili (Binary) Lojistik Regresyon Analizi Sonuçları

\begin{tabular}{lcc}
\hline & Ürün Yeniliği & \\
Bağımsız Değişkenler & $(\beta)$ & $(\mathrm{SH})$ \\
\hline Patent/FM & $0,561^{* * *}$ & 0,066 \\
\hline Tasarımın sicil kaydı & 0,020 & 0,069 \\
\hline Telif hakk1 & $-0,274 * * *$ & 0,075 \\
\hline Marka tescili & $0,579^{* * *}$ & 0,056 \\
\hline Üretim süresi avantaj1 & $0,468^{* * *}$ & 0,055 \\
\hline Tasarımın karmaşıklığ1 & $0,384^{* * *}$ & 0,065 \\
\hline Gizlilik & 0,055 & 0,063 \\
\hline Sabit & $-2,511^{* * *}$ & 0,105 \\
$\mathrm{~N}$ & 4.549 & \\
-2Log Likelihood & $3.123,65$ & \\
Nagelkerke Pseudo $\mathrm{R}^{2}$ & 56,5 & \\
Sinıflandırma başarıs1 & $\% 85,2$ & \\
\hline$* * * \mathrm{p}<, 001$. & &
\end{tabular}

Ürün yeniliği ile pozitif ve anlamlı ilişkiler sırasıyla marka, patent/FM, üretim süresi avantajı ve tasarımın karmaşıklığı arasındadır. Bu bulgu, hem resmi hem de resmi olmayan koruma yöntemlerinin ürün yeniliğini pozitif olarak etkilediğini göstermektedir. Tasarımın sicil kaydı ve gizlilik ise ürün yeniliğinin korunmasında her ne kadar pozitif olmasına rağmen anlamlı bir katk1 sağlamamaktadır. Dikkat çekici olan ise telifin, istatistiksel olarak anlamlı ve negatif etkisinin olmasıdır. Nitekim Thomä ve Bizer (2013) telifi 'diğer SM koruması', Lall (2003) 'gevşek SM koruması (lax IPRs)' olarak tanımlamışlardır. Telif hakları, yazılım gibi bazı teknolojik konuları içermesine rağmen telif koruması teknik veya işlevsel yenilikleri kapsamamaktadır. $\mathrm{Bu}$ nedenle çalışmanın müteakip analizlerinde telif haklarına yer verilmemiştir.

Çalışmanın bu bölümünde, 4.549 imalât sanayi firmasının icra ettikleri yenilik faaliyetleri dikkate alınarak farklı gruplar oluşturup oluşturmadığını görmek maksadıyla kümeleme analizi yapılmıştır. Sırasıyla hiyerarşik ve hiyerarşik olmayan k-ortalama kümeleme algoritmaları kullanılmıştır. İlk aşamada, uç değerleri belirlemek ve yenilik faaliyetlerine dayalı olarak nispeten homojen küme sayısını bulmak amacıyla hiyerarşik kümeleme analizi yapılmıştır. Optimum küme sayısına karar vermek için Öklit Uzaklığının Karesi uygulanarak Varyans (Ward) Tekniği kullanılmış ve 4 kümeli bir çözüm elde edilmiştir. Sonraki aşamada belirlenen dört küme ile k-ortalama kümeleme yeniden çalıştırılarak örneklemi oluşturan gözlemler niteliklerine göre belirli bir kümeye tahsis edilmiştir. Sonrasında kümelerin farklılıklarını değerlendirmek ve küme 
sonuçlarının doğruluklarını teyit etmek amacıyla, her boyutta her bir küme için ortalamalar bir siralama tabanlı parametrik olmayan test olan Kruskal-Wallis kullanılarak incelenmiştir. Dört küme arasında gerçekleştirilen yenilik faaliyetleri açısından istatistiksel olarak anlamlı bir fark olduğu ortaya konmuştur.

Tablo 3. Küme Özetleri

\begin{tabular}{|c|c|c|c|c|c|c|c|c|c|c|c|}
\hline & \multicolumn{3}{|c|}{1} & \multicolumn{3}{|c|}{2} & \multicolumn{3}{|c|}{3} & \multicolumn{2}{|c|}{ ruskal-Wallis test } \\
\hline & $\mathrm{N}=706$ & $\%$ & Ort & $\mathrm{N}=415$ & $\%$ & Ort & $\mathrm{N}=733$ & $\%$ & Ort & d.f & Chi-square \\
\hline Girişim Bünyesinde Ar-Ge & 500 & 70,8 & \multirow{2}{*}{, 29} & 178 & 42,9 & \multirow{2}{*}{, 57} & 101 & 13,8 & \multirow{2}{*}{, 86} & \multirow{2}{*}{3} & \multirow{2}{*}{$481,5 * * *$} \\
\hline $\begin{array}{l}\text { Girişim Bünyesinde Ar-Ge } \\
1\end{array}$ & 206 & 29,2 & & 237 & 57,1 & & 632 & 86,2 & & & \\
\hline $\begin{array}{l}\text { Dişarıdan Temin Edilen } \\
\text { Ar-Ge Hizmetleri } 0\end{array}$ & 670 & 94,9 & \multirow{2}{*}{, 05} & 354 & 85,3 & \multirow{2}{*}{, 15} & 342 & 46,7 & \multirow{2}{*}{, 53} & \multirow{2}{*}{3} & \multirow{2}{*}{$469,1 * * *$} \\
\hline $\begin{array}{l}\text { Dişarıdan Temin Edilen } \\
\text { Ar-Ge Hizmetleri } 1\end{array}$ & 36 & 5,1 & & 61 & 14,7 & & 391 & 53,3 & & & \\
\hline $\begin{array}{l}\text { Yeniliğe yönelik makine, } \\
\text { teçhizat, yazılım temini } 0\end{array}$ & 287 & 40,7 & \multirow{2}{*}{, 59} & 87 & 21 & \multirow{2}{*}{,79 } & 61 & 8,3 & \multirow{2}{*}{,92 } & \multirow{2}{*}{3} & \multirow{2}{*}{$214,1 * * *$} \\
\hline $\begin{array}{l}\text { Yeniliğe yönelik makine, } \\
\text { teçhizat, yazılım temini } 1\end{array}$ & 419 & 59,3 & & 328 & 79 & & 672 & 91,7 & & & \\
\hline Diğer Dişsal Bilgiler 0 & 668 & 94,6 & \multirow{2}{*}{, 05} & 334 & 80,5 & \multirow{2}{*}{,20 } & 263 & 35,9 & \multirow{2}{*}{, 64} & \multirow{2}{*}{3} & \multirow{2}{*}{$609,7 * * *$} \\
\hline Diğer Dışsal Bilgiler 1 & 38 & 5,4 & & 81 & 19,5 & & 470 & 64,1 & & & \\
\hline Yeniliğe Yönelik Eğitim 0 & 659 & 93,3 & \multirow{2}{*}{, 07} & 256 & 61,7 & \multirow{2}{*}{, 38} & 101 & 13,8 & \multirow{2}{*}{, 86} & \multirow{2}{*}{3} & \multirow{2}{*}{$929,7 * * *$} \\
\hline Yeniliğe Yönelik Eğitim 1 & 47 & 6,7 & & 159 & 38,3 & & 632 & 86,2 & & & \\
\hline $\begin{array}{l}\text { Yeniliklerin Pazarda } \\
\text { Tanıtımı } 0\end{array}$ & 616 & 87,3 & \multirow{2}{*}{, 13} & 211 & 50,8 & \multirow{2}{*}{,49 } & 139 & 19 & \multirow{2}{*}{, 81} & & \\
\hline $\begin{array}{l}\text { Yeniliklerin Pazarda } \\
\text { Tanıtımı } 1\end{array}$ & 90 & 12,7 & & 204 & 49,2 & & 594 & 81 & & 3 & 672 \\
\hline Tasarım 0 & 625 & 88,5 & 1 & 209 & 50,4 & 50 & 68 & 9,3 & 91 & 3 & $0053 * * *$ \\
\hline Tasarım 1 & 81 & 11,5 & & 206 & 49,6 & (50 & 665 & 90,7 & (91 & & \\
\hline Diğer Hazırlıklar 0 & 625 & 88,5 & & 252 & 60,7 & 39 & 93 & 12,7 & & & \\
\hline Diğer Hazırlıklar 1 & 81 & 11,5 &, 11 & 163 & 39,3 & ,39 & 640 & 87,3 &, 87 & 3 & $844,8 \cdots \cdots$ \\
\hline Ürün Yeniliği 0 & 296 & 41,9 & & 144 & 34,7 & & 144 & 19,6 & & 3 & \\
\hline Ürün Yeniliği 1 & 410 & 58,1 & 81 & 271 & 65,3 & 033 & 589 & 80,4 & 304 & 3 & $2.64 /, 9 \cdots \cdots$ \\
\hline Küme & $\begin{array}{r}\text { Düş } \\
\mathrm{a}\end{array}$ & $\begin{array}{l}\text { ik yen } \\
\text { tivitel }\end{array}$ & & $\begin{array}{r}\text { Orta } \\
\text { ak } \\
\end{array}$ & $\begin{array}{l}\text { yenili } \\
\text { tiviteli }\end{array}$ & & $\begin{array}{r}\text { Yüks } \\
\mathrm{ak}\end{array}$ & $\begin{array}{l}\text { ek yen } \\
\text { tiviteli }\end{array}$ & lik & & \\
\hline Örneklemdeki Oranı & & 615,5 & & & 79,1 & & & 16,1 & & & \\
\hline
\end{tabular}

*** Anlamlılık düzeyi \% 1 .

Son küme çözümünü gösteren Tablo 3'te firmalar üç ana gruba ayrılmaktadır. Koruma ile yenilik faaliyetlerinin birbirini olumlu yönde etkilediği kabulü doğrultusunda, örneklemin büyük bir çoğunluğu olan \% 59,2'sini oluşturan (2.695 firma) ve yenilik aktivitesinde bulunmayan ' 0 ' kümesinin değerlerine tabloda yer verilmemiştir. İcra ettikleri yenilik faaliyetlerine göre farklılaşan diğer üç grup; Düşük, Orta ve Yüksek yenilik aktiviteli olarak isimlendirilmiştir. Kruskal-Wallis testi, tüm yenilik faaliyetlerinde gruplar arasında anlamlı bir farklılık olduğunu göstermektedir. Yürütülen faaliyet sayısı ve ortalama değerleri, grup sayısı düşük yenilik aktivitesinden yükseğe doğru artmaktadır. Düşük ve Orta aktiviteli kümelerde, yeniliğe yönelik makine, teçhizat, bina ve yazılım temini ile iç Ar-Ge faaliyetleri en fazla icra edilen faaliyetlerdir. İkinci kümede, tasarım ve tanıtım faaliyetlerinde dikkat çekici bir artış görülmektedir. Üçüncü kümenin ise yeniliğe yönelik tüm faaliyetlerdeki 
etkinliği ile diğer kümelerle önemli oranda farklılaştığı dikkat çekmektedir. Yeniliğe yönelik makine, teçhizat, bina ve yazılım temini yine ilk sırada yer alırken tasarım faaliyeti ikinci sıraya yükselmektedir.

Tablo 4. Benimsenen Stratejilere Yönelik Faktör Analizi Sonuçları

Faktör Yükleri

\begin{tabular}{|c|c|c|c|c|c|}
\hline \multirow[b]{2}{*}{ Maddeler } & & \multirow[b]{2}{*}{$\begin{array}{l}\text { Faktör } \\
\text { İsimleri }\end{array}$} \\
\hline & Faktör 1 & Faktör 2 & Faktör 3 & Faktör 4 & \\
\hline $\begin{array}{l}\text { Avrupa Ülkeleri'nde yeni } \\
\text { pazarların geliştirilmesi }\end{array}$ & & ,911 & & & \multirow{2}{*}{$\begin{array}{c}\text { Pazarlama } \\
\text { Stratejisi }\end{array}$} \\
\hline $\begin{array}{l}\text { Avrupa dışında yeni pazarların } \\
\text { geliştirilmesi }\end{array}$ & & ,901 & & & \\
\hline $\begin{array}{l}\text { Girişim-içi operasyon } \\
\text { maliyetlerinin azaltılması }\end{array}$ & & & 843 & & \multirow{2}{*}{$\begin{array}{l}\text { Maliyet } \\
\text { Stratejisi }\end{array}$} \\
\hline $\begin{array}{l}\text { Malzeme, bileşen ve hizmet } \\
\text { maliyetlerinin azaltılması }\end{array}$ & & &, 855 & & \\
\hline $\begin{array}{l}\text { Piyasaya yeni ya da önemli ölçüde } \\
\text { geliştirilmiş mal ya da hizmet } \\
\text { sürülmesi }\end{array}$ & 847 & & & & \multirow{3}{*}{$\begin{array}{l}\text { Yenilik } \\
\text { Stratejisi }\end{array}$} \\
\hline $\begin{array}{l}\text { Mal ya da hizmetlerin pazarlama } \\
\text { faaliyetlerinin yoğunlaştırılması ya } \\
\text { da geliştirilmesi }\end{array}$ & ,794 & & & & \\
\hline $\begin{array}{l}\text { Organizasyon yapısının } \\
\text { esnekliğinin/tepkisinin artırılması }\end{array}$ &, 565 & & & & \\
\hline $\begin{array}{l}\text { Diğer girişim ya da kuruluşlar ile } \\
\text { anlaşma yapılması }\end{array}$ & & & & ,915 & $\begin{array}{l}\text { İşbirliği } \\
\text { Stratejisi }\end{array}$ \\
\hline Açıklanan Varyans (\%) & 24,69 & 23,78 & 23,34 & 15,27 & \\
\hline Toplam Açıklanan Varyans (\%) & & & 87,08 & & \\
\hline Cronbach Alpha $(\alpha)$ & & & 0,895 & & \\
\hline
\end{tabular}

- Boşluklar faktör yükü <,5 göstermektedir.

Araştırmada firmalara, amaçlarına ulaşmak için uyguladıkları stratejilere verdikleri önem hakkındaki görüsslerini ölçmek üzere sorulan 8 sorunun, sıralı lojistik regresyon modellerinde daha kolay yorumlanması ve birbiriyle ilişkili olanların bir araya getirilmesi amacıyla keşfedici faktör analizi uygulanmıştır. Faktör analizinin uygunluğu iki standart ölçüt incelenmek suretiyle belirlenmiştir. Örnekleme yeterliliği ölçüsü Kaiser-Meyer-Olkin ve Bartlett's test of sphericity $(46.021,61, \mathrm{p}<, 000)$ tatmin edici sonuçlar vermiştir. Sonraki aşamada bu faktörlere; bağımsızlık, yorumlamada açıklık ve anlamlılık sağlamak amacıyla bir eksen döndürmesi (varimax rotation) uygulanmış ve toplam varyansın çoğunluğunu açıklayan 4 faktörlü bir optimal çözüm elde edilmiştir. Tablo 4 , ölçek maddelerini, döndürülmüş faktör yüklerini, faktör isimlerini ve her değişken için açıklanan toplam varyansı göstermektedir. Faktör yük değerinin, 0,45 ya da daha yüksek olması seçim için iyi bir ölçüdür (Büyüköztürk, 2006). Sonuçlardan görüleceği gibi tüm faktör yükleri 0,5 'in üzerindedir ve bu da ölçeklerin geçerliliğini desteklemektedir. İlk faktörde yer alan maddelerin tümünün yeni pazar geliştirme ile ilişkili olduğu dikkate alınarak bu faktöre "pazarlama 
stratejisi" ismi verilmiştir. Faktör 2 maliyetlerin düşürülmesi ile ilgili olduğu için "maliyet stratejisi", diğer faktörler sırasıyla "yenilik stratejisi" ve "işbirliği stratejisi" olarak isimlendirilmiştir. Güvenilirlik analizi sonucunda, ölçeğin güvenilir olduğunun söylenebilmesi için alfa katsayı değerinin $0,7^{\prime}$ 'den yüksek olması beklenmektedir (Nunnaly, 1978). Her faktör için alfa değerleri 0,7'nin üzerinde olduğu için bu kriter karşılanmaktadır. Sonuçlar, ölçeğin güvenilirliğini ve geçerliliğini desteklemektedir. Sonraki aşamada faktörler, regresyon modelinde bağımsız değişken olarak kullanılmıştır.

$\mathrm{Bu}$ bölümde, farklı yenilik koruma mekanizmalarına yönelik algıların, firmanın yenilikle ilgili iç ve dış faaliyetlere katılımı ile nasıl etkilendiği analiz edilmektedir. Katılımcılardan, "etkisi yok", "zayıf", "orta" ve "yüksek" arasında değişen dörtlü Likert ölçeği kullanılarak koruma yöntemlerine verilen önemin değerlendirilmesi istenmiştir. Bağımlı değişken olarak kullanılan, firmaların koruma yöntemlerine verdikleri öneme yönelik değerlendirmeleri sıralı ölçeğe uygun olduğundan, SM koruma tercihlerinin belirleyicilerinin ve etki derecelerinin tespit edilmesi amacıyla sıralı lojistik regresyon analizi yapılmıştır. Analiz neticesinde elde edilen bulgular Tablo 5'te sunulmuştur. Regresyonda kullanılan firma düzeyindeki açıklayıcı değişkenler tablonun ilk sütununda yer almaktadır. Altı adet denklemin katsayılarının eşit olup olmadığını belirlememizi sağlayan Wald Chi kare ve pseudo log likelihood testleri, altı denklemin önemli ölçüde birbirinden farklı ve her değişkenin koruma yöntemlerini farklı oranda etkileyebildiğini göstermektedir.

Tablo 5. Siralı Lojistik Regresyon Analizi Sonuçları

\begin{tabular}{|c|c|c|c|c|c|c|c|c|c|c|c|c|}
\hline \multirow{2}{*}{$\begin{array}{l}\text { Bağımlı } \\
\text { değiskenler } \\
\text { Bağımsız } \\
\text { değişkenler }\end{array}$} & \multicolumn{2}{|c|}{ Patent/FM } & \multicolumn{2}{|c|}{$\begin{array}{l}\text { Tasarımın } \\
\text { sicil kaydı }\end{array}$} & \multicolumn{2}{|c|}{ Marka tescili } & \multicolumn{2}{|c|}{$\begin{array}{l}\text { Uretim süresi } \\
\text { avantaj1 }\end{array}$} & \multicolumn{2}{|c|}{$\begin{array}{c}\text { Tasarımın } \\
\text { karmaşıklığı }\end{array}$} & \multicolumn{2}{|c|}{ Gizlilik } \\
\hline & $\begin{array}{l}\text { Beta } \\
(\beta)\end{array}$ & S.H & Beta $(\beta)$ & S.H. & Beta $(\beta)$ & S.H. & Beta $(\beta)$ & S.H. & $\begin{array}{l}\text { Beta } \\
(\beta)\end{array}$ & S.H & Beta $(\beta)$ & S.H. \\
\hline $\begin{array}{l}\text { Pazar } \\
\text { büyüklüğg̈ }\end{array}$ & ,024 & $\begin{array}{c}, 01 \\
5\end{array}$ & ,025 & ,016 &, $058 * * *$ &, 015 &, $026 \dagger$ &, 015 &, 014 & $\begin{array}{c}, 01 \\
5\end{array}$ & ,025 & ,016 \\
\hline $\begin{array}{l}\text { Iç Ar-Ge } \\
\text { harcamaları }\end{array}$ & ,030 & $\begin{array}{c}, 02 \\
4\end{array}$ &, 037 &, 024 &, $048^{*}$ &, 024 &, 001 &, 024 &, $047^{*}$ & $\begin{array}{c}, 02 \\
4\end{array}$ &, $055^{*}$ &, 024 \\
\hline $\begin{array}{l}\text { Dış Ar-Ge } \\
\text { harcamalar1 }\end{array}$ &, $045 \dagger$ & $\begin{array}{c}, 02 \\
4\end{array}$ &,- 025 &, 024 &, $021 \dagger$ &, 025 &, $047^{*}$ &, 024 &,- 005 & $\begin{array}{c}, 02 \\
4\end{array}$ &,$- 043 \dagger$ &, 024 \\
\hline $\begin{array}{l}\text { Kurum içi } \\
\text { bilgi } \\
\text { kaynakları } 0\end{array}$ & $\begin{array}{c}- \\
, 252^{*} \\
* *\end{array}$ & $\begin{array}{c}, 20 \\
9\end{array}$ &,$- 172 * *$ &, 211 & $-404^{* * * *}$ &, 210 & ${ }^{-}, 362^{* * *}$ &, 210 & $\begin{array}{c}- \\
, 121^{* *} \\
*\end{array}$ & $\begin{array}{c}, 20 \\
8\end{array}$ &, $109^{* * *}$ &, 211 \\
\hline \multicolumn{13}{|l|}{$\begin{array}{l}\text { Kurum içi } \\
\text { bilgi } \\
\text { kaynakları 1 }\end{array}$} \\
\hline $\begin{array}{l}\text { Piyasa bilgi } \\
\text { kaynakları } 0\end{array}$ & $\begin{array}{c}- \\
609 * \\
*\end{array}$ & $\begin{array}{c}, 22 \\
6\end{array}$ &,$- 531 *$ &, 240 & $\begin{array}{c}- \\
, 821^{* * *}\end{array}$ &, 221 & $\begin{array}{c}- \\
1,205^{* *} \\
*\end{array}$ &, 220 & $\begin{array}{c}- \\
, 847 * * \\
*\end{array}$ & $\begin{array}{c}, 23 \\
1\end{array}$ &,$- 589 *$ &, 242 \\
\hline $\begin{array}{l}\text { Piyasa bilgi } \\
\text { kaynakları } 1\end{array}$ & Ref. & & Ref. & & Ref. & & Ref. & & Ref. & & Ref. & \\
\hline $\begin{array}{l}\text { Üni/Arşt. } \\
\text { kurumları } \\
\text { bilgi kay } 0\end{array}$ & $\begin{array}{c}- \\
800^{*} \\
* *\end{array}$ & $\begin{array}{c}, 13 \\
4\end{array}$ & $\begin{array}{c}- \\
, 920^{* * *}\end{array}$ &, 135 &,- 177 &, 136 &, 164 &, 136 &,$- 329 *$ & $\begin{array}{c}, 13 \\
2\end{array}$ & , $653^{* * * *}$ & ,134 \\
\hline $\begin{array}{l}\text { Üni/Arşt. } \\
\text { kurumları } \\
\text { bilgi kay } 1\end{array}$ & Ref. & & Ref. & & Ref. & & Ref. & & Ref. & & Ref. & \\
\hline $\begin{array}{l}\text { Diğer bilgi } \\
\text { kaynakları } 0\end{array}$ &, 075 & $\begin{array}{c}, 18 \\
2\end{array}$ &,- 239 &, 188 &,- 217 &, 181 &,- 227 &, 181 &,$- 418^{*}$ & $\begin{array}{c}, 18 \\
1\end{array}$ &,$- 379 *$ & , 188 \\
\hline
\end{tabular}




\begin{tabular}{|c|c|c|c|c|c|c|c|c|c|c|c|c|}
\hline $\begin{array}{l}\text { Diğer bilgi } \\
\text { kaynaklari } 1\end{array}$ & Ref. & & Ref. & & Ref. & & Ref. & & Ref. & & Ref. & \\
\hline $\begin{array}{l}\text { Finansal } \\
\text { destek alma } \\
0\end{array}$ &, $122 *$ & $\begin{array}{c}, 12 \\
4\end{array}$ &, 123 &, 126 &, 041 &, 128 &,$- 035^{*}$ &, 128 &,- 064 & $\begin{array}{c}, 12 \\
4\end{array}$ &,- 061 &, 125 \\
\hline $\begin{array}{l}\text { Finansal } \\
\text { destek alma } \\
1\end{array}$ & Ref. & & Ref. & & Ref. & & Ref. & & Ref. & & Ref. & \\
\hline $\begin{array}{l}\text { Diğer } \\
\text { firmalar ile } \\
\text { işbirliği } 0\end{array}$ & $\begin{array}{c}- \\
615^{*} \\
*\end{array}$ & $\begin{array}{c}, 26 \\
0\end{array}$ &,- 140 &, 260 &,- 164 &, 275 &, 057 &, 275 &,- 070 & $\begin{array}{c}, 25 \\
9\end{array}$ &,$- 440 \dagger$ & ,261 \\
\hline $\begin{array}{l}\text { Diğer } \\
\text { firmalar ile } \\
\text { işbirliği } 1\end{array}$ & Ref. & & Ref. & & Ref. & & Ref. & & Ref. & & Ref. & \\
\hline $\begin{array}{l}\text { Müşteriler } \\
\text { ile işbirliği } 0\end{array}$ &, 113 & $\begin{array}{c}, 23 \\
2\end{array}$ &,- 093 &, 232 &,- 064 &, 242 &,$- 432 \dagger$ &, 244 &,- 205 & $\begin{array}{c}, 23 \\
0\end{array}$ &,$- 386 \dagger$ &, 231 \\
\hline $\begin{array}{l}\text { Müşteriler } \\
\text { ile işbirliği } 1\end{array}$ & Ref. & & Ref. & & Ref. & & Ref. & & Ref. & & Ref. & \\
\hline $\begin{array}{l}\text { Bilgi } \\
\text { merkezleri } \\
\text { ile isbirliği } 0\end{array}$ & $\begin{array}{c}- \\
, 550 * \\
*\end{array}$ & $\begin{array}{c}, 21 \\
4\end{array}$ &, 237 &, 214 &, 265 &, 222 &, 330 &, 221 &, 054 & $\begin{array}{c}, 21 \\
2\end{array}$ &,$- 398 \dagger$ & ,214 \\
\hline $\begin{array}{l}\text { Bilgi } \\
\text { merkezleri } \\
\text { ile issbirliği } 1\end{array}$ & Ref. & & Ref. & & Ref. & & Ref. & & Ref. & & Ref. & \\
\hline $\begin{array}{l}\text { Yenilik } \\
\text { faaliyeti } 0\end{array}$ & $\begin{array}{c}- \\
26,61 \\
5 * * *\end{array}$ & $\begin{array}{c}1,2 \\
3\end{array}$ & $\begin{array}{c}- \\
7,523 * * \\
*\end{array}$ & $\begin{array}{c}1,03 \\
1\end{array}$ & $\begin{array}{c}- \\
8,164 * * \\
*\end{array}$ & $\begin{array}{c}1,02 \\
9\end{array}$ & $\begin{array}{c}- \\
8,336^{* *} \\
*\end{array}$ & $\begin{array}{c}1,02 \\
8\end{array}$ & 26,178 & 0 & $7,254 * *$ & $\begin{array}{c}1,03 \\
2\end{array}$ \\
\hline $\begin{array}{l}\text { Yenilik } \\
\text { faaliyeti } 1\end{array}$ & $363^{*}$ & $\begin{array}{c}, 14 \\
6\end{array}$ &,$- 459 * *$ &, 148 &,- 186 &, 150 & $493 * * *$ &, 149 & $423 * *$ & $\begin{array}{c}, 14 \\
5\end{array}$ &,$- 305^{*}$ &, 148 \\
\hline $\begin{array}{l}\text { Yenilik } \\
\text { faaliyeti } 2\end{array}$ & $\begin{array}{c}- \\
.380 * \\
.\end{array}$ & $\begin{array}{c}, 15 \\
1\end{array}$ &,$- 446 * *$ &, 153 &,$- 458 * *$ &, 154 &,$- 307 *$ &, 154 &,- 186 & $\begin{array}{c}15 \\
0\end{array}$ &,$- 338 *$ & ,153 \\
\hline $\begin{array}{l}\text { Yenilik } \\
\text { faaliyeti } 3\end{array}$ & Ref. & & Ref. & & Ref. & & Ref. & & Ref. & & Ref. & \\
\hline $\begin{array}{l}\text { Pazarlama } \\
\text { stratejisi }\end{array}$ &, 073 & $\begin{array}{c}, 06 \\
6\end{array}$ &, $155^{*}$ &, 067 &, 080 &, 067 &, $135^{*}$ & ,068 &, 010 & $\begin{array}{c}, 06 \\
6\end{array}$ &, 101 & ,067 \\
\hline $\begin{array}{l}\text { Maliyet } \\
\text { stratejisi }\end{array}$ & $\begin{array}{c}- \\
, 215^{*} \\
*\end{array}$ & $\begin{array}{c}, 08 \\
2\end{array}$ &,- 119 & ,083 &,$- 193^{*}$ & ,082 &, 085 &, 081 &,- 043 & $\begin{array}{c}, 08 \\
1\end{array}$ &,- 081 & ,083 \\
\hline $\begin{array}{l}\text { Yenilik } \\
\text { stratejisi }\end{array}$ & $\begin{array}{l}446^{*} \\
* *\end{array}$ & $\begin{array}{c}, 09 \\
9\end{array}$ &, $317 * *$ &, 101 &, $765^{* * *} *$ &, 102 &, $412 * * *$ & ,099 & $\begin{array}{c}434 * * \\
*\end{array}$ & $\begin{array}{c}, 09 \\
9\end{array}$ &, $164 \dagger$ & ,101 \\
\hline $\begin{array}{l}\text { İşbirliği } \\
\text { stratejisi }\end{array}$ & ,085 & $\begin{array}{c}, 06 \\
1\end{array}$ &, $151^{*}$ &, 061 &,- 036 &, 063 &, $111 \dagger$ &, 062 &, $144^{*}$ & $\begin{array}{c}, 06 \\
1\end{array}$ &, $248 * * *$ & ,062 \\
\hline $\begin{array}{l}-2 \log \\
\text { likelihood }\end{array}$ & \multicolumn{2}{|c|}{$3.039,63$} & \multicolumn{2}{|c|}{$2.992,5$} & \multicolumn{2}{|c|}{$2.839,07$} & \multicolumn{2}{|c|}{$2.868,15$} & \multicolumn{2}{|c|}{$3.070,6$} & \multicolumn{2}{|c|}{$2.996,24$} \\
\hline$\chi^{2}$ & \multicolumn{2}{|c|}{$2.700,65^{* * *}$} & \multicolumn{2}{|c|}{$2.469,4 * * *$} & \multicolumn{2}{|c|}{$3.337,38 * * *$} & \multicolumn{2}{|c|}{$3.558,23 * * *$} & \multicolumn{2}{|c|}{$2.985,74 * * *$} & \multicolumn{2}{|c|}{$2.494,27 * * *$} \\
\hline Pseudo $\mathrm{R}^{2}$ & \multicolumn{2}{|c|}{64,8} & \multicolumn{2}{|c|}{62,2} & \multicolumn{2}{|c|}{72,3} & \multicolumn{2}{|c|}{74} & \multicolumn{2}{|c|}{67,8} & \multicolumn{2}{|c|}{62,5} \\
\hline N & \multicolumn{2}{|c|}{4.549} & \multicolumn{2}{|c|}{4.549} & \multicolumn{2}{|c|}{4.549} & \multicolumn{2}{|c|}{4.549} & \multicolumn{2}{|c|}{4.549} & \multicolumn{2}{|c|}{4.549} \\
\hline
\end{tabular}

Bağımsız değişkenlerin, bağımlı değişkenler üzerindeki etkisine yönelik Pseudo $\mathrm{R}^{2}$ değerleri yüzde 62,2 ile 74 arasında değişmektedir. Bu sonuç, bağımsız değişkenlerin, bağımlı değişkenler üzerinde önemli ölçüde etkiye sahip olduğunu göstermektedir. Bağımsız değişkenlerin beta değerleri incelendiğinde, imalât sanayi sektöründe kurum içi ve piyasa temelli bilgi kaynakları ile yenilik stratejisi, tüm bağımlı değişkenler üzerinde pozitif ve istatistiksel olarak anlamlı etkiye sahiptir. Firmaların, yenilik stratejisi benimseyerek, firma dışı bilgileri kullanma ve iç bilgi kaynakları ile içselleştirme düzeylerini artırması durumunda, yenilikçilik seviyelerinde ve dolayısıyla tüm koruma yöntemlerinde önemli bir artış oluşmaktadır. 
Pazar büyüklüğü ile pozitif ve istatistiksel olarak en önemli ilişki tescilli marka arasındadır. Üretim süresi avantajının etki derecesi anlamlı ancak oldukça düşüktür. Pazarını genişleten firmaların marka gücünden yoksun olarak, pazar payını elinde bulunduran gelişmiş rakiplerle mücadele etmeleri ve pazarlarını daha da geliştirmeleri zordur. Bu nedenle, uzun vadede çok büyük emek ve sermaye yatırımı gerektirmesine rağmen, pazarın büyümesi ile birlikte markalaşma ve markanın avantajlarından yararlanma öncelikli olarak tercih edilmektedir.

Firma içi Ar-Ge harcamaları ve aktiviteleri arttıkça tescilli marka ile birlikte özellikle resmi olmayan koruma yöntemlerinden gizlilik ve tasarımın karmaşıklı̆̆ 1 tercihlerinde bir artış meydana gelmektedir. Bu bulgu, Brouwer ve Kleinknecht (1999)'in, iç Ar-Ge'ye odaklanan firmaların gizliliğe daha fazla önem vermekte olduğu bulgusu ile örtüşmektedir. Kendi bünyelerinde $\mathrm{Ar}-\mathrm{Ge}$ faaliyeti yürüten ve yenilik geliştiren firmaların, patent/FM gibi bürokratik işlemler gerektiren ve hem başvuru hem de devamında maliyet yükü taşıyan koruma yöntemlerini tercih etmedikleri görülmektedir. Söz konusu koruma yöntemlerinin taklide karşı takibi de firmaların zorlandıkları ve tercihlerini etkileyen bir başka durumdur.

Dış Ar-Ge harcamaları arttıkça firmaların, üretim süresi avantaj1, patent/FM ve tescilli marka koruma yöntemlerini benimsemeleri daha muhtemel iken gizlilik tercihinde ise tersine bir durum söz konusudur. Dışarıdan sağlanan Ar-Ge'nin daha çok resmi koruma yöntemlerine firmaları yönlendirmesinin, ortaya çıkan bağımlılık durumundan kaynaklandığı öne sürülebilir. Nitekim Gallié ve Legros (2012), yasal koruma yöntemlerinin, dışarıdan Ar-Ge sağlayan ve yüksek pazar payına sahip firmalar tarafından daha fazla tercih edildiğini belirlemiştir.

Kurum içi bilgi kaynakları incelendiğinde, tüm yöntemlerde pozitif etkisi olmasına rağmen, en fazla oranda sırasıyla tescilli marka, üretim süresi avantajı ve patent/FM tercihlerini etkilediği görülmektedir. $\mathrm{Bu}$ bulgu, koruma ve rekabetçilik açısından değerli olan firma içi bilginin ürüne dönüşmesiyle birlikte pazarda ilk olmadan kaynaklanacak avantajlardan yararlanılmasına, marka konumunun oluşturulmasına ve nihayetinde ürünün patentlenerek üründen uzun süreli faydalanılmasına yardımcı olduğunu göstermektedir.

Günümüzde özellikle küçük firmaların, çalışan sayısı ve çeşitliliği açısından dış bilgiye ihtiyacı daha fazladır. Çünkü firmaların dış bilgi kaynaklarından yararlanarak Ar-Ge faaliyetleri yürütmesi daha fazla yenilik geliştirmelerini sağlamaktadır. Piyasa bilgi kaynaklarının koruma stratejileri üzerindeki en önemli ve anlamlı etkisi üretim süresi avantaj1 tercihi üzerinedir. Bunu tasarımın karmaşıklığı ve tescilli marka stratejisi izlemektedir. Bilgi kaynağı olarak üniversite/araştırma kuruluşlarından faydalanan firmaların resmi koruma yöntemleri olan tasarımın sicil kaydı ve patent/FM'i benimseme olasılığ daha yüksektir. Patent/FM'e ilişkin olumlu tutuma yönelten temel uygulamalardan biri de temel ve uygulamalı teknolojiler üzerinde çalışma yapan 
bilimsel kurumlar tarafından firmalara verilen eğitimler ve danışmanlık hizmetleri olabilecektir. Gizlilik ve tasarımın karmaşıklı̆g 1 stratejilerinin ise etki dereceleri diğerlerine göre biraz düşüktür. Diğer bilgi kaynaklarından (konferanslar, ticari fuarlar, sergiler, bilimsel dergiler, ticari/teknik yayınlar, dernekler, meslek ve sanayi odaları) faydalanma sadece gizlilik ve tasarımın karmaşıklı̆̆ yöntemlerinin seçilmesi ihtimali üzerinde pozitif bir etkiye sahiptir. Çünkü bu bilgi, iç Ar-Ge yeteneğinin geliştirilmesi amacıyla kullanılmaktadır.

Finansal destek alan firmaların yalnızca patent/FM ve üretim süresi avantajlarına yöneldikleri görülmektedir. Destek alınan kuruluşlarla yapılan sözleşmeler, patent/FM tercihine yol açmakla birlikte, maddi açıdan firmaların patent/FM maliyetlerini karşılamasına yardımcı olmaktadır. Kay vd (2014) de yaptıkları çalışmada, finansal desteklerin firmaların patent elde etmesinde pozitif etkisinin olduğunu belirlemiştir. Ayrıca edinilen desteklerle sağlanan bilgi, danışmanlık, ekipman ve benzer kabiliyetler üretim sürelerinin kısaltılmasında önem taşımaktadır.

Firmaların çalışmakta olduğu ortakların tipi, koruma tutumlarını belirlemede önemli bir değişkendir. Diğer firmalarla işbirliklerinin patent/FM ve gizlilik üzerinde pozitif ve anlamlı bir ilişkisi bulunmaktadır ancak etki derecesi patent/FM için yüksektir. Firmalar patent/FM gibi yasal bir koruma yöntemini tercih ederek rakipleri ile yaşayabilecekleri olası bir anlaşmazlıkta problem yaşanmasını önlemek isteyeceklerdir. Nitekim Laursen ve Salter (2014), sadece güçlü koruma stratejisine sahip firmaların rakipleri ile işbirliği faaliyetlerinde bulunacağını savunmaktadırlar. Literatürde yapılan çalışmalarda da diğer firmalarla yapılan işbirliklerinin, ortaklarla bilgi paylaşımını gerektirdiğinden, patentlemenin önemli görülme olasılığını artırdığı teyit edilmiştir (Leiponen ve Byma, 2009; Blind vd, 2006; Peeters ve Pottelsberghe de la Potterie, 2006; Gallié ve Legros, 2012). Gizliliğin tercih edilmesi sonucunda patentleme gerektirecek kapsamlı işbirliklerinin yürütülmemesi, uzun vadede patentle ilgili maliyetlerin şirketler arasında problemler doğurabilme ihtimali ya da kültürden kaynaklanan karşılıklı güven ilişkilerine bağlı olduğu ifade edilebilir.

Müşterilerle işbirliği ile üretim süresi avantajı ve gizlilik arasında pozitif ve anlamlı ilişki bulunmaktadır. Üretim süresi avantajı ve gizlilik, büyük oranda müşteri talepleri doğrultusunda tercih edilmektedir. Yeni ürün geliştiren firmalar sürekli olarak müşterilerle çok yakın temas içinde bulunarak kullanıcı ihtiyaçlarını en ideal şekilde karşılamak üzere işbirliği yaparlar. Yapılan bu işbirliklerinde müşteriler de önemli bir paydaş olmaktadır. Büyük oranda artımsal yenilikler geliştirme ve ürün iyileştirmesi olanağı sağlayan bu tür işbirlikleri, maliyetli olan yasal koruma yöntemlerinin tercih edilme ihtimalini düşürecektir. Müşteriler öncelikli olarak, geliştirilecek ürünün en kısa sürede ya da istedikleri zamanda kullanımlarına sunulmasını talep edeceklerdir. Ayrıca, bazı ortak projelerde işbirliği sonucunda elde edilecek ürün bilgilerinin gizli kalmasının müşteriler tarafından talep edilmesinin olası olduğu ifade edilebilir. Bilgi merkezleri ile işbirliği yapanlar ile patent/FM ve gizlilik arasında pozitif ve anlamlı bir ilişki bulunmaktadır ancak etki derecesi patent/FM için yüksektir. 
Çünkü firma ve bilgi merkezleri arasında karşılıklı olarak varılan mutabakatlar, projelerin temel araştırma boyutunda gizli kalmasına veya ürüne dönüşen bilginin, ürünün piyasada büyük oranda yeni özellikler taşıyacak olmasından dolayı patent/FM'e yönlendirecektir. Özetle, rakipler ve bilgi merkezleri ile işbirlikleri genel olarak patent/FM'in önemli görülmesine neden olmaktadır.

Farklı derecede yenilik faaliyetinde bulunan firma grupları, yoğun olarak ürün ve süreç yeniliğine yönelik faaliyet yürüten üçüncü gruptaki firmalarla karşılaştırılmıştır. Bu gruptaki firmalar diğer gruptakilere göre daha fazla yenilik geliştirmek için iç ve diş Ar-Ge hizmetleri yürütmekte, makina, teçhizat ve yazılım temin etmekte, eğitim, tanıtım, tasarım ve diğer hazırlık faaliyetleri gerçekleştirmektedirler. Bilgi tabanlı ve işbirliğine dayalı yenilik geliştirme üzerinde güçlü bir odaklanma eğilimindedirler. Yüksek oranda yenilik faaliyeti gerçekleştiren firmaların gerçekleştirmeyenlere oranla patent/FM tercihinde bulunma ihtimalinin oldukça yüksek olduğu dikkat çekmektedir. Tasarımın karmaşıklı̆̆ında ise ilişki anlamlı değildir. Diğer tüm koruma tercihlerinde, yüksek yenilik kümesindeki firmaların düşük ve orta yenilik kümesinden daha yüksek oranda korumaya yöneldikleri görülmektedir. Bu bulgu, yenilikle koruma arasındaki doğrusal ilişkiyi teyit etmesinin yanında patent/FM tercihinin etkisini göstermesi açısından önemlidir.

Pazarlama stratejisi benimseyen firmaların koruma stratejilerinden, tasarımın sicil kaydı ve üretim süresi avantajını kullanmayı tercih ettiği görülmektedir. Diğer koruma yöntemleri ise istatistiki olarak anlamlı değildir. Her ne kadar piyasada patent/FM'e sahip ürünlerin arkasında önemli bir $\mathrm{Ar}-\mathrm{Ge}$ çalışması olduğu değerlendirilerek tüketici tercihlerinde önemli ölçüde etkili olacağı kabul edilmesine rağmen tasarım ve üretim süresi, firmalar tarafından daha önemli görülmektedir. Görsel olarak ayırt edilecek özellikler kazandırılması, kalite algısının güçlendirilmesi ve rakipler tarafından ürünün taklit edilmesinin zorlaştırılması bu tercihe neden olabilir. Maliyet stratejisinin etki dereceleri yalnızca patent/FM ve marka tescili için anlamlı ve negatif yönlüdür. Maliyet stratejisinin diğer yöntemler üzerinde anlamlı bir etkisi bulunmamaktadır. Maliyetlerini azaltmak isteyen firmaların maliyet getiren bu yöntemleri kullanmaktan kaçınmaları doğal bir sonuçtur. Yenilik stratejisinin daha önce belirtildiği gibi tüm yöntemler üzerinde istatistiksel olarak anlamlı ve pozitif etkisi mevcuttur. En yüksek etki ise marka tescili üzerindedir. Bu durum yenilikle koruma arasındaki karşılıklı ve pozitif ilişkilerin olduğunun bir göstergesidir. İşbirliği stratejisi ise resmi olmayan yöntemlerin tümü ve tasarımın sicil kaydı ile ilişkilidir. Rekabetçi avantaj kazanma ve güçlenme işbirlikleri ile mümkündür. Yukarıda sunulan bulgular, işbirliği aktiviteleri ve işbirliği stratejilerinin ortalamaların tüm kümelerde oldukça düşük olduğunu göstermiştir. Yenilik geliştirmeye dayalı işbirliği kültürünün firmalar ve diğer aktörlerle yeterince geliştirilmediği veya sınırlı oranda kaldığı bir ortamda işbirliği yapılan tarafların koruma isteklerinin ve ihtiyacının da o oranda az olması doğaldır. 


\section{SONUÇ}

Sağladığı ekonomik ve bir dizi stratejik avantajlarından dolayı firmalar ve kuruluşlar tarafından SM'in önemi her geçen gün daha da anlaşılmaktadır. Çünkü teknoloji izleme faaliyetlerinde gerçekleştirilen SM incelemelerinden elde edilen yeni bilgilerden yenilik sürecinin girdi aşamasında, SM çıktılarından ise firma performanslarının değerlendirilmesinde yararlanılmaktadır. $\mathrm{Bu}$ değerden istifade etmek isteyen ve yenilikçi ürün geliştiren firmalar öncelikle SM varlıkları oluşturmakta, müteakiben bunları korumak için farklı stratejiler benimsemektedirler.

SM korumasında ve özellikle patent/FM sayılarında gelişmiş ülkelerin oldukça gerisinde kalan gelişmekte olan bir ülkede yapılan bu çalışma, büyük bir örneklemle, farklı büyüklükteki firmaların sahip oldukları bilginin korunmasına verdikleri önemi ve yönelimlerini etkileyen, pazar büyüklüğü, Ar-Ge aktiviteleri, finansal destekler gibi geleneksel faktörlerin yanısıra, organizasyonlar arası çeşitli işbirliklerinin, farklı bilgi kaynaklarının ve kurumsal stratejilerin, koruma stratejilerinin oluşumundaki rolünü anlamak amacıyla yapılmıştır. 4.549 imalât sanayi firmasından alınan veriler kullanılarak, ikili lojistik regresyon, kümeleme, keşfedici faktör ve sıralı lojistik regresyon analizleri uygulanarak firmaların SM koruma tercihleri ortaya konmuştur.

Çalışmanın temel bulgusu, firmaların koruma sağlamak maksadıyla içinde bulundukları koşullar ve kurumsal stratejiler doğrultusunda resmi ve resmi olmayan yöntemler arasından tercihte bulunduğudur. Ayrıca korumanın ön şartlarından birisi olan ürün yeniliği, telif hakkı dişında, hem resmi hem de resmi olmayan koruma yöntemleri ile pozitif ilişkilidir. Marka tescili, patent/FM ve üretim süresi avantaj1, ürün yeniliğini anlamlı olarak en fazla oranda etkileyen koruma yöntemleridir. Ar-Ge faaliyetlerinin boyutu arttıkça ve ürün sunulan pazar genişledikçe, marka tescilinin etkililiğine yönelik değerlendirmeler de olumlu yönde artmakta, bu bulguyu, yenilik stratejisi benimseyen firmaların en fazla oranda marka tesciline odaklanması da teyit etmektedir. Uluslararası pazarlara açılan firmaların rekabet avantajı kazanmak için öncelikle marka oluşumuna öncelik verdiği anlaşılmaktadır. Marka oluşturma ve pazara ilk girme çabalarının patent/FM ile desteklenmesi, artan küresel rekabetin ve zaman baskısının sonucu olarak küresel pazarlara yeni ürünlerle sorunsuzca girilmesi stratejisinin bir parçasıdır.

Yüksek oranda yenilik faaliyeti gerçekleştirmeye çalışan ya da gerçekleştiren firmaların, gerçekleştirmeyenler, düşük ve orta seviyede bu faaliyetleri yürütenlere oranla özellikle patent/FM tercihinde ve genel olarak tüm koruma tercihlerinde korumaya daha fazla yönelimli oldukları görülmektedir. Yenilik stratejisi benimseyen, kurum içi ve piyasa bilgi kaynaklarından faydalanan firmalar tüm koruma yöntemlerini önemli bulmaktadırlar. Firmanın dışa dönük faaliyetlerinden, diğer firmalar, bilgi merkezleri ve üniversite araştırma kuruluşları ile işbirliği ve bilgi edinme faaliyetleri, özellikle iç Ar-Ge'ye dayanan içe-dönük yenilik stratejisinden daha çok aktif bir patent/FM koruma davranışı ile ilişkilidir. Bilimsel kurumlar ile işbirliklerinin firmaları patent/FM ve 
tasarımın sicil kaydı korumasına yöneltmesi, doğası gereği patentlenebilir bilgi ile sonuçlanan temel araştırma faaliyetlerinden ticari ürün ortaya çıkarma başarısı sağlandığını göstermektedir.

Çalışmadan elde edilen bir diğer önemli bulgu, iç Ar-Ge harcamasının gizliliğe, dış Ar-Ge harcamasının ise patent/FM'e yöneltiyor olmasıdır. Dış Ar-Ge yatırımı gerçekleştiren firmaların gizlilik tercihlerinde ise anlamlı ve negatif etki söz konusudur. Diğer firma ve bilgi merkezleri ile işbirliklerinde patent/FM ve gizlilik birbirlerinin tamamlayıcısıdır. Dış kuruluşlarla ortak Ar-Ge faaliyetleri yürütülmesi, belirli seviyede, ortakların bilgi tabanlarına karşılıklı erişime olanak sağlamaktadır (Peeters ve Pottelsberghe de la Potterie, 2006). Bu tür bir ortaklık, özellikle rakip firmalarla işbirlikleri durumunda, SM koruması için daha yüksek bir ihtiyaca neden olmaktadır. Firmalar ve bilgi merkezleri arasında karşılıklı varılacak mutabakatlarla faaliyetlerin ve geliştirilen yeniliklerin tamamının ya da bir kısmının gizli kalması yönünde de ortak hareket edilebileceği anlaşılmaktadır.

Alınan finansal destekler, patent/FM edinimini pozitif olarak etkilemekte ve daha aktif koruma davranışı sergileme olasılığını yükseltmektedir. Gelişmekte olan bir ülkede yenilikçi ve teknolojik gelişmeler, değerli bilgiler edinmek ve finansman sağlamak için diğer kuruluşlarla olan bağlantılara bağlıdır. Ampirik bulgular, finansal teşviklerin firmaların patent/FM alma kararlarında önemli bir pozitif etkiye sahip olduğunu göstermektedir. $\mathrm{Bu}$ nedenle maddi desteklerin etkisini, yalnızca yenilik geliştirme aşamalarında değil, aynı zamanda patent/FM edinim sürecinde de gösterdiği söylenebilir. Maliyet stratejisi benimseyen firmaların patent/FM ve marka tescili konusunda sahip oldukları negatif alg1, söz konusu yöntemlerin firmalar açısından doğurduğu mali yükün bir yansımasıdır.

Türkiye'deki SMH'na ilişkin eğilimi belirlemeye yardımc1 olacağı düşünülen bu çalışmanın en önemli sınırlaması, farklı koruma yöntemleri konusunda firmaların değerlendirmelerinin Likert tipi ölçekle alınan cevaplara dayalı olmasıdır. Her bir SM korumasının somut uygulamaları yerine, firmaların algılarına odaklanılmas1, korumanın yalnızca tek boyutunun incelenmesi sonucunu doğurmaktadır. Bunu ortadan kaldırmak için, gelecekte yapılacak çalışmalarda, gerçekleştirilen başvurular ve koruma uygulamaları gibi göstergelerin kullanılması faydalı olacaktır. Çalışmanın bir başka sınırlaması, tek bir veri kaynağının kullanılmasıdır. Çalışmanın güvenilirliğinin artırılması maksadıyla çoklu cevaplar ve farklı veri tabanlarından istifade edilebilir. Gelecekte yapılacak çalışmalarda, yenilik geliştirme ve koruma üzerindeki etkisi olan zorlukların vaka analizlerinden de yararlanılarak araştırılması faydalı olacaktır. 


\section{KAYNAKÇA}

Amara, N., Landry, R. and Traoré, N. (2008). Managing The Protection of Innovations in Knowledge-Intensive Business Services. Research Policy, Vol. 37, 1530-1547.

Blind, K., Edler, J., Frietsch, R. and Schmoch, U. (2006). Motives to Patent: Empirical Evidence from Germany. Research Policy, Vol. 35, 655-672.

Brouwer, E. and Kleinknecht, A. (1999). Innovative Output, and A Firm's Propensity to Patent: An Exploration of CIS Micro Data. Research Policy, Vol. 28, 615-624.

Büyüköztürk, Ş. (2006). Sosyal Bilimler İçin Veri Analizi El Kitabı (6. Baskı), Ankara: Pegem.

Cassiman, B. and Veugelers, R. (2002). R\&D Cooperation and Spillovers: Some Empirical Evidence from Belgium. American Economic Review, Vol. 92, No. 4, 1169-1184.

Chesbrough, H.W. (2003). Open Innovation: The New Imperative for Creating and Profiting from Technology. Harvard Business School Press, Boston, MA.

Cohen, W.M., Nelson, R.R. and Walsh, J. (2000). Protecting Their Intellectual Assets: Appropriability Conditions and Why US Manufacturing Firms Patent (or not). SSRN Working Paper No. 7552, 1-50.

Delerue, H. and Lejeune, A. (2011). Managerial Secrecy and Intellectual Asset Protection in SMEs: The Role of Institutional Environment. Journal of International Management, Vol. 17, $130-142$.

Dericioğlu, K. (2005). Türkiye'de Ulusal Patent Sayıları. Erişim Tarihi 12 Aralık 2016, http://www.inovasyon.org/getfile.asp?file=Turkiye'deki_Ulusal_Patent_Sayilari.pdf

Duguet, E. and Kabla, I. (1998). Appropriation Strategy and The Motivation to Use The Patent System: An Econometric Analysis at the Firm Level in French Manufacturing. Annales d'Économie et de Statistique, 49/50, 289-327.

Elche, D. (2011). Sources of Knowledge, Investments and Appropriability as Determinants of Innovation: An Empirical Study in Service Firms. Innovation: Management, Policy \& Practice, Vol. 13, 220-235.

Eren, H. ve Kılıç, A. (2016). Firmalarda Patent ve Faydalı Model Edinim Stratejisini Etkileyen Faktörler. International Journal of Management Economics \& Business, Vol. 12, Iss. 28, 189-208.

Frenz, M. and Prevezer, M. (2012). What can CIS Data Tell Us about Technological Regimes and Persistence of Innovation? Industry and Innovation, Vol. 19, No. 4, 285-306.

Gallié, E.P. and Legros, D. (2012). French Firms' Strategies for Protecting Their Intellectual Property. Research Policy, Vol. 41, 780-794.

Hanel, P. (2008). The Use of Intellectual Property Rights and Innovation by Manufacturing Firms in Canada. Economics of Innovation and New-Technology, Vol. 17, 285-309.

Kaufmann, A. and Tödtling, F. (2001). Science-Industry Interaction in the Process of Innovation: The Importance of Boundary-Crossing Between Systems. Research Policy, Vol. 30, 791804.

Kay, L., Youtie, J. and Shapira, P. (2014). Signs of Things to Come? What Patent Submissions by Small and Medium-Sized Enterprises Say About Corporate Strategies in Emerging Technologies. Technological Forecasting \& Social Change, Vol. 85, 17-25.

Keller, W. (2004). International Technology Diffusion. Journal of Economic Literature, Vol. 42, $752-782$.

Kim, Y.K., Lee, K., Park, W.G. and Choo, K. (2012). Appropriate Intellectual Property Protection and Economic Growth in Countries at Different Levels of Development. Research Policy, Vol. 41, 358-375.

Lall, S. (2003). Indicators of the Relative Importance of IPRs in Developing Countries. Research Policy, Vol. 32, 1657-1680.

Laursen, K. and Salter, A.J. (2014). The Paradox of Openness: Appropriability, External Search and Collaboration. Research Policy, Vol. 43, 867-878.

Lederman, D. and Saenz, L. (2005). Innovation and Development Around the World, 1960-2000. World Bank Policy Research Working Paper 3774, 24-26.

Leiponen, A. and Byma, J. (2009). If You cannot Block, You Better Run: Small Firms, Cooperative Innovation, and Appropriation Strategies. Research Policy, Vol. 38, 1478-1488. 
Lerner, J. (1999). The Government as Venture Capitalist: The Long-Run Impact of the SBIR Program. Journal of Business, Vol. 72, No. 3, 285-318.

Levin, R.C., Klevorick, A.K., Nelson, R.R. and Winter, S.G. (1987). Appropriating the Returns from Industrial Research and Development', Brookings Papers on Economic Activity, Vol. 3, 783-820.

Löfsten, H. and Lindelöf, P. (2002). Science Parks and The Growth of New Technology-Based Firms Academic-Industry Links, Innovation and Markets. Research Policy, Vol. 31, 859876.

Macdonald, S. (2004). When Means Becomes Ends, Considering The Impact of Patent Strategy on Innovation. Information Economics and Policy, Vol. 16, No. 1, 135-158.

Markman, G.D., Espina, M.I. and Phan, H.P. (2004). Patents as Surrogates for Inimitable and NonSubstitutable Resources. Journal of Management, Vol. 30, No. 4, 529-544.

Nonaka, I. and Takeuchi, H. (1995). The Knowledge-Creating Company: How Japanese Companies Create the Dynamics of Innovation. New York: Oxford University.

Nunnaly, J.C. (1978). Psychometric Theory. New York: McGraw Hill.

Oliver, J.L.H. and Ripoll, F.S. (2015). Disentangling the Influence of Technological Process and Product Innovations. Journal of Business Research, Vol. 68, No. 1, 109-118.

Olsson, H. and McQueen, D.H. (2000). Factors Influencing Patenting in Small Computer Software Producing Companies. Technovation, Vol. 20, 563-576.

Peeters, C. and van Pottelsberghe de la Potterie, B. (2006). Innovation Strategy and the Patenting Behavior of Firms. J Evol Econ, Vol. 16, 109-135.

Pekol, Ö. ve Erbaş, B.Ç. (2011). Patent Sisteminde Türkiye'deki Teknoparkların Yeri. Ege Akademik Bakış, Cilt XI, 39-58.

Shukla, D.B. (2005). Need to Inculcate the Culture of Intellectual Property Protection in Research and Development. Current Science, 1553-1561.

Sichelman, T. and Graham, S.J.H. (2010). Patenting by Entrepreneurs: An Empirical Study. 17 Mich. Telecomm. Tech. L. Rev. 111. Erişim Tarihi 12 Kasım 2016, http://www.mttlr.org/volseventeen/Sichelman\&Graham.pdf

Sobrero, M. and Roberts, E.B. (2002). Strategic Management of Supplier-Manufacturer Relations in New Product Development. Research Policy, Vol. 31, No. 1, 159-182.

Tether, B.S. (2002). Who Co-Operates for Innovation, and why: An Empirical Analysis. Research Policy, Vol. 31, 947-967.

Thomä, J. and Bizer, K. (2013). To Protect or not to Protect? Modes of Appropriability in the Small Enterprise Sector. Research Policy, Vol. 42, 35-49.

TPE, (2015). Patent/Faydal Model. Erişim Tarihi 12 Aralık 2016, http://www.tpe.gov.tr/TurkPatentEnstitusu/commonContent/Publications

Uysal, F. (2012). Patent ve Faydalı Model Edinim Eğilimlerini Etkileyen Faktörler; Ankara'daki Teknoparklarda Yerleşik Firmalar Üzerine Bir Araştırma. (Yayınlanmamış YL Tezi). KHO Sav.Bil.Enstitüsü, Ankara.

WIPO, (2012). WIPO IP Facts and Figures. Erişim Tarihi 13 Eylül 2016, http://www.wipo.int/edocs/pubdocs/en/statistics/943/wipo_pub_943_2012.pdf

WIPO, (2016). What is Intellectual Property?, Erişim Tarihi 23 Aralık 2016, http://www.wipo.int/about-ip/en/

Yalçıner, U.G. and Akın, A. (2009). State Supports (Incentives) for Patent Applications. TED: Technology and Economic Development $3^{\text {rd }}$ International Conference on Innovation, Technology and Knowledge Economics. 


\section{SUMMARY}

The creation and diffusion of knowledge is crucial in every stages of innovation process for firms and desirable for growth and wellbeing of nations. Once created, valuable knowledge is required to be protected from disclosure and imitation. In order to protect knowledge, nations become part of international trade organizations and sign protective agreements and firms use various approaches to shelter their Intellectual Property (IP). This article explores the IP protection in a developing country by using a set of factors that may drive IP protection method preferences of firms and the importance they attach to the protection. A developing country has been selected for a better understanding and filling potential research gaps by determining the degree of influence of diverse factors that may have impacts on firms' protection strategies. In addition to the above mentioned factors, an investigation of the role of different corporate strategies chosen by firms not included in the previous studies was conducted. To shed light on aims, firm-level data of Turkish Statistical Institute Innovation Survey 2012 was used to provide empirical estimates. Both descriptive and multivariate methods were used to study the impact of factors on protection strategies. The analysis focuses on inputs including different types of corporate strategies and cooperation in addition to traditional factors such as market size, R\&D activities, knowledge sources and funds.

Since this study is dealing with the roles of manufacturing industry, 4,549 firms with non-missing values was drawn from the sample. A binary logistic regression analysis was conducted to provide a better understanding of protection choices made by firms and to predict the impact of each method on the extent to which firms engage in product innovation. Regarding firms' choices of the most important method for protecting products, trademark, patent/UM, complexity of design and lead-time advantages have positive and significant effects. As for the copyrights, effect is negative and significant. Although copyrights include some technological issues their protection does not cover technical or functional novelty. For that reason copyright was excluded from the subsequent analysis. A cluster analysis on 4,549 cases was conducted in order to view whether firms form distinct groups regarding their undertaken innovation activities. Both the hierarchical and the k-means techniques were used successively. The final cluster solution that firms differentiated into three major groups: low, medium and high innovative activity.

Despite being in early stages of IP system, firms use both formal and informal protection mechanisms under different circumstances. Our results confirm that trademark registration, patent/UM and lead-time advantages are the protection methods that significantly influence product innovation. Patents/UM protection behavior of firms is mostly associated with having an innovation strategy and outward-oriented innovation activities. Internal and market-based information sources and innovation strategy have a positive effect on all protection methods. There is a positive and significant relationship between market scope, $R \& D$ expenditures and level of importance given to trademark. It is 
clear that companies opening to international markets give priority to brand formation in order to gain competitive advantage. Firms that are trying to implement or perform high-level innovation activities seem to be more inclined to protect, especially in the patent/UM preference, and generally in all protection preferences, than low and middle level performers. Another important finding from the study is that internal R\&D expenditure leads to secrecy and external $R \& D$ expenditure leads to patent/UM. In addition patent/UM and secrecy are complementary to each other in cooperation with other firms and information centers. Firms who get financial support also attribute higher importance to patent/UM and exhibit more active protection behaviors. 